Louisiana State University

LSU Digital Commons

Faculty Publications

Department of Geography \& Anthropology

1996

\title{
The ecological origins and consequences of cattle ranching in sixteenth-century New Spain
}

Andrew Sluyter

Louisiana State University, asluyter@lsu.edu

Follow this and additional works at: http://digitalcommons.lsu.edu/geoanth_pubs

\section{Recommended Citation}

Sluyter, Andrew, "The ecological origins and consequences of cattle ranching in sixteenth-century New Spain" (1996). Faculty Publications. 61.

http://digitalcommons.lsu.edu/geoanth_pubs/61

This Article is brought to you for free and open access by the Department of Geography \& Anthropology at LSU Digital Commons. It has been accepted for inclusion in Faculty Publications by an authorized administrator of LSU Digital Commons. For more information, please contact gcoste1@lsu.edu. 


\title{
The Geographical Review
}

VOLUME 86

April 1996

NUMBER 2

\section{THE ECOLOGICAL ORIGINS AND CONSEQUENCES OF CATTLE RANCHING IN SIXTEENTH-CENTURY NEW SPAIN*}

\begin{abstract}
ANDREW SLUYTER
ABSTRACT. Despite the dramatic landscape changes Mexico has undergone due to the introduction of cattle ranching by the Spaniards in the early sixteenth century, the ecological origins of that pastroecosystem have remained obscure. About 1521, Gregorio de Villalobos implanted an Andalusian-derived herding ecology in the Gulf Coast lowlands that involved seasonal movement of cattle between wetlands and hill lands. Land-grant records demonstrate that as the colonial economy expanded, the transhumant model proliferated and came into conflict with those native settlements that had survived the pandemics of the early sixteenth century. In circumventing viceregal laws meant to protect native cultures and ecologies, ranchers prevented their recovery; the consequences persist to the present. Keywords: cattle, landscape ecology, native depopulation, New Spain, Veracruz.
\end{abstract}

The two most important things to know about Mexico still are the patterns of life that existed before the coming of the white men and the changes that were introduced during the first generation or two of the Spanish period.

-Carl O. Sauer, "The Personality of Mexico," 1941

Livestock have occupied the Mexican scene since the sixteenth-century birth of New Spain, early and pervasively contributing to the ecological upheaval of "the Columbian exchange" (Crosby 1972; Butzer 1992; Turner and others 1995). The Spaniards brought livestock both large and small. Along with those cattle, horses, mules, donkeys, sheep, goats, and pigs arrived a suite of ecological institutions that have left decisive imprints on the landscape. The landscape, reciprocally, has left its imprint on institutions. An association of herders organized the transhumant routes bywhich

\footnotetext{
* William E. Doolittle and Alfred H. Siemens have long and generously shared their enthusiasm for the Mexican landscape and given freely of their knowledge and interpretive skills. The staffs of the Archivo General de la Nación and the Benson Latin American Collection of the University of Texas at Austin as well as the people of Veracruz have made research in archive and field as pleasant as it is intellectually rewarding. Funding from the National Aeronautics and Space Administration and the University of Texas at Austin made this research possible.
}

20 Dr. SluYter is an assistant professor of geography at the Pennsylvania State University, University Park, Pennsylvania 16802. 
sheep moved between seasonal pastures along hundreds of kilometers of stonewalled trails, or cañadas. The estancias, or land grants, gridded the landscape league by league, accumulating space for Spaniards and marginalizing natives. The pastures burned each long, dry winter, incrementally altering the vegetation.

Yet despite a deep and broad imprint on the Mexican landscape, cattle ranching's sixteenth-century ecological origins have remained obscure. An orthodox literature long emphasized Spain's semiarid plateau-often, specifically, Estremadura-as the Old World hearth of New Spain's ranching ecology (Bishko 1952; Brand 1961; Rouse 1977).Supposedly, a fully developed ecology and economy involving mounted herders and transhumance diffused southward with the Reconquista into Andalusia and, ultimately, through Seville and across the Atlantic to NewSpain. Morerecently, revisionists have combined archival and field research to hypothesize that cattle ranching involving mounted herders reached its Old World apogee along the lower Río Guadalquivir of Andalusia, in the seasonally inundated marshes known as Las Marismas, and from there diffused to New Spain (Doolittle 1987; Butzer 1988; Jordan 1993).

To date, contrasts between the sixteenth-century livestock ecologies of Estremadura and Andalusia provide the main support for the revisionist hypothesis. Sheep predominated on the semiarid plateau, and the image of mounted Estremadurans herding cattle across sparse, semiarid grasslands is as much myth as icon. In contrast, cattle predominated in Andalusia, and as the floodwaters of the Río Guadalquivir receded each spring, herders drove their stock into Las Marismas (Figure 1). Largely untended during the long dry season, isolated among a labyrinth of sloughs, the animals became semiferal. Solanos blowing out of Africa parched the oak-pine savannas of the surrounding hills, which the ranchers set ablaze in late summer (Fernández Alés, Martín, and Merino 1995, 366). As the rains returned each October, herders required horses to round up the semiferal stock before the Guadalquivir flooded and drive them up to the fresh regrowth of the hill pastures.

The Andalusian provenance of the original conquistadores, the four hundred or so who sailed with Cortes, further supports the revisionist hypothesis. Nearly a third of the conquistadores hailed from the provinces bordering Las Marismas-Seville, Huelva, Cádiz-and knew its transhumant pulse (Boyd-Bowman 1964, xli). Having witnessed the fecundity of the cattle Columbus had introduced into Hispaniola in 1493, those Andalusians extended the diffusion to New Spain during the sixteenth century (Sauer 1966; Watts 1987). In a few decades, the lowland plains along the Gulf of Mexico, an environmental homologue to coastal Andalusia, had become the domain of vast cattle herds (Simpson 1952; Butzer and Butzer 1995). By 1580 the viceroys had granted sixty-two cattle estancias in the lowland environs of the port of Veracruz alone, and the report of the alcalde claims 150,000 cows and mares (JGI, xxV-8, f. 5; Sluyter 1995).

Understanding of the ecological processes and consequences involved in that cataclysmic landscape change, particularly its initial stage, remains as incipient for Veracruz as for Mexico as a whole (Butzer and Butzer 1995). Yet the Veracruz lowlands hold particular relevance for understanding the ecological changes that ensued from 


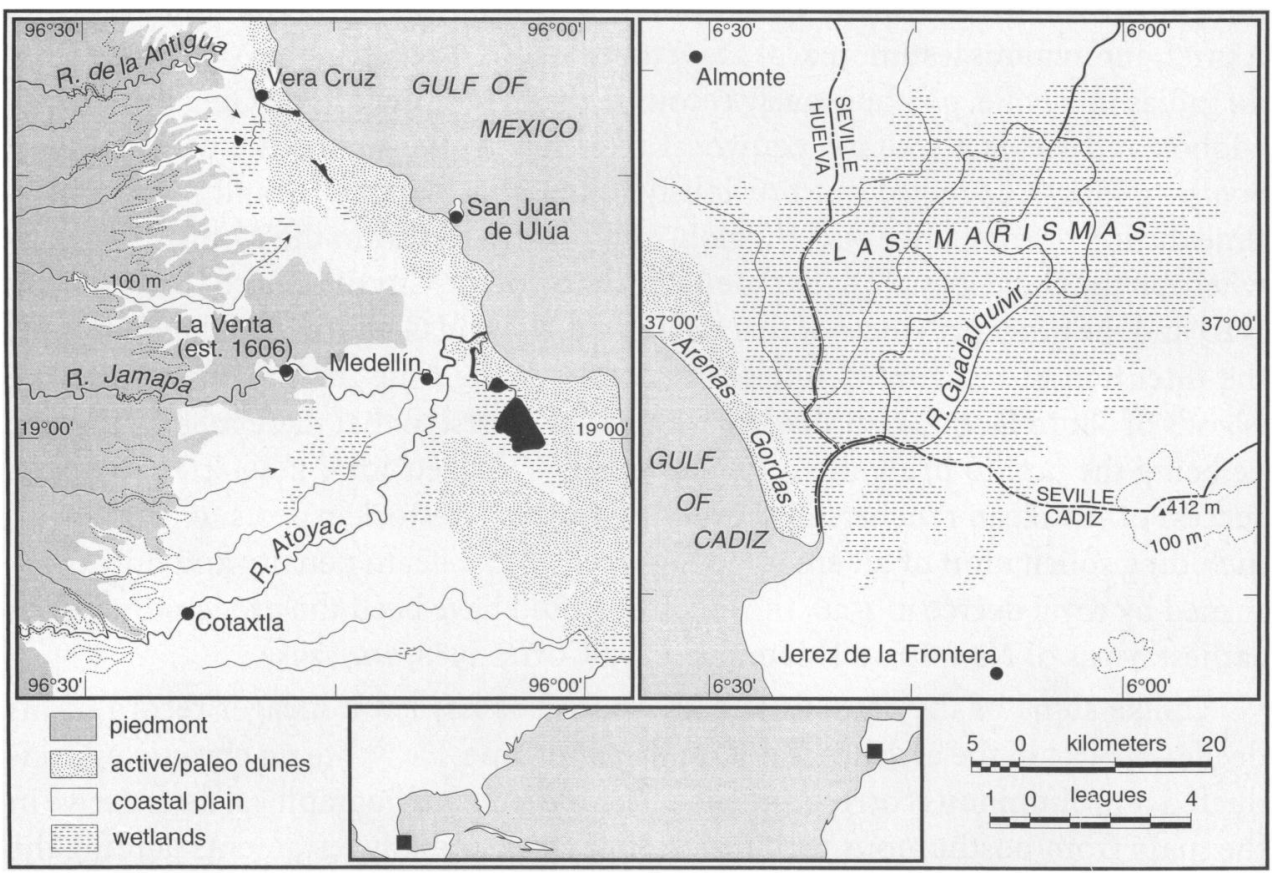

Fig. 1-The lowlands of Veracruz and Andalusia, with relevant settlements of circa 1525. Sources: Gran atlas de España 1989; Jordan 1993.

the colonization of Mesoamerica. The region formed the beachhead for the invasion and became the entrepot for the subsequent colony, bearing the first brunt of the war, the disease, and the livestock. That prominence makes the brevity of the literature on sixteenth-century landscape changes in those lowlands all the more inexplicable (Melgarejo Vivanco 1943, 1975; Kelly and Palerm 1952; González Jácome 1988; Siemens 1995; Sluyter 1995).

Despite the relative paucity of previous research, the revisionist hypothesis of an Andalusian rather than an Estremaduran hearth suggests that the first herds of New Spain would have followed a seasonal rhythm analogous to the transhumance of Las Marismas, ranging between the marshes and hills of the Gulf Coast lowlands. Although those first cattle have left no more than a few archival tracks, some data do support that hypothesis by confirming diffusion of open-range ranching from the Guadalquivir lowland to the environs of the port of Veracruz. More specifically, those data reveal how a Spaniard named Gregorio de Villalobos first adapted the transhumant ecology of Las Marismas to the Gulf Coast lowlands as well as its relationship to native settlement and ecology.

\section{The First Cattle}

Sometime and somewhere during the anarchistic 1520s, well before the first viceroy began to quell the unruly conquistadores with land grants during the 1540 , cattle 
ranching began in New Spain. Yet the provenance of those first herds remains vague. A brief, anonymous testimonial of 22 October 1554, preserved in the Archivo General de Indias in Seville, posthumously recounts the biography of one Gregorio de Villalobos and yields a solitary, equivocal reference to the first cattle to reach New Spain-a long-recognized but previously uninvestigated clue (Brand 1961). Sometime during or soon after 1521, Villalobos shipped calves from the Antilles to somewhere on the Gulf Coast: "[A]fter the pacification of the City of Mexico [on 13 August 1521] and the other provinces of this New Spain, the said Gregorio de Villalobos, with the intention of remaining in it permanently, at the time that he came from the islands of Santo Domingo brought a number of calves, so that there might be cattle, he being the first to bring them to New Spain" (Hackett 1923, 1: 40-41). Given the success of Antillean ranchers in preventing further livestock exports to New Spain, including solicitation of an embargo enforced with a death penalty and only overturned by royal decree in 1526, those calves would have been the progenitors of the earliest herds of New Spain (Matesanz 1965; Cortés 1988, 204-205).

Unlike some of the conquistadores, Villalobos has left a meager record of his deeds-at least in the archives if not on the landscape. He wrote no chronicles, conducted no voluminous correspondence. The few known biographical facts derive in the main from posthumous memorials, similar to so many testaments lauding the past services of conquistadores in order to secure lasting privilege for their scions (Hackett 1923, 1: 40; Icaza 1923, 1: 223).

The extant biographical fragments neither contradict nor confirm that Villalobos brought the first cattle to New Spain. Villalobos hailed from Almonte, on the northern margin of Las Marismas. His parents had come from Jerez de la Frontera, to the south. The shipping lists of Seville record Villalobos's passage to the Antilles in 1516, when he was just twenty-two years old (Boyd-Bowman 1964, 59). On the island of Cuba two years later, he heard of Grijalva's encounter with Montezuma's emissaries at San Juan de Ulúa. In 1521, two years after Cortés had left Cuba and six months before the fall of Tenochtitlán, Villalobos went to Mexico to ride with the conquistadores, arriving at Villa Rica de la Vera Cruz aboard a ship of reinforcements (Boyd-Bowman 1968, 150; Díaz del Castillo 1986, 310). ${ }^{1}$ Cortés ordered the latecomer to remain as part of the garrison at Villa Rica, and he became one of its citizens and served as alderman and mayor. By 1526 Villalobos was living at Medellín (Figure 1), a town Cortés had founded along the lower Río Jamapa in the early 1520s, and serving as "mayordomo de Cortés" (Díaz del Castillo 1986, 505; Cortés 1988, 199). Eventually, the exact year being uncertain, he relocated from the Gulf Coast lowlands to the highlands, moving to Puebla de los Angeles and again serving as alderman and alcalde (Dorantes de Carranza 1987, 173). His primary reward for helping to conquer Mexico was the encomienda of Ixhuatlán, a grant of native tribute midway between Puebla and Veracruz, with the natives thereby commended to his charge providing him with a tribute of 100 pesos a year (Scholes and Adams 1955, 33). He and Beatriz García de la Fuente married sometime after 1527, that being the year her first husband died, and they raised a daughter and two sons. Villalobos died sometime before 1547, 
the encomienda going to a son. By 1565 that successor had also died, and the encomienda reverted to the Crown (Himmerich y Valencia 1991, 261).

That brief biography contains no direct references to New Spain's prototypic estancia-to the place Villalobos grazed, raised, and increased those original calves, to the environments involved, or to the herding ecology and its relationship to native settlement and ecology. Because the viceregal scribes did not begin to record land grants until 1542, no entry for a cattle estancia in the name of Gregorio de Villalobos appears in the volumes of mercedes, or land grants, preserved in the Archivo General de la Nación in Mexico City (Chevalier 1952). Yet some of those land-grant documents do contain pertinent data, albeit long unappreciated and ignored, which do confirm that Villalobos imported the first cattle and adapted the Andalusian transhumant ecology to the Veracruz lowlands.

\section{The First Estancia}

A grant of 1583 for a cattle estancia along the lower Río Jamapa refers to previous occupance by a Gabriel de Villalobos, one of Gregorio's two sons, ${ }^{2}$ and identifies the general location of the Villalobos estancia: "[G]rant to Juan de la Párraga for one cattle estancia in the district of the city of Vera Cruz amid the estancia of Gonzalo de Alegría and Francisco de Cocas that was wont to belong to Gabriel de Villalobos on the other side of the Río Jamapa" (AGN, Mercedes, vol. 13, f. 20). ${ }^{3}$ The Mercedes volumes do not record a grant to Francisco de Cocas for the Veracruzan lowlands. But, in 1573, Gonzalo de Alegría did receive a cattle estancia, although the actual merced has not survived. Only the writ ordering an inspection of the requested estancia remains. And even that writ, as if nested in a maze of folios, appears only within the context of yet another document: an inspection report prompted by Juan Rodríguez de Villegas's 1575 request for an estancia (AGN, Tierras, vol. 2764, exp. 18, ff. 225-260). Although the viceroy apparently never granted Villegas his request, due to opposition by one Pedro Núñez de Montalván, both the map accompanying the Villegas report and the Párraga merced itself confirm the existence of the Alegría estancia. Thus the estancia "that was wont to belong to Gabriel de Villalobos" lay between the Río Jamapa and the Río Atoyac, named "El Río Grande de Medellín" on the 1575 map (Figure 2), somewhat upstream from their confluence and on the inner margin of the coastal plain.

A 1606 grant of an inn to Francisco Párraga, presumably a son of Juan de la Párraga, confirms and more closely specifies the location:

[B] ecause Licenciado Francisco Párraga citizen of the new city of Vera Cruz [transferred from the left bank of the Río de la Antigua to San Juan de Ulúa circa $1600]$. . has his stocked cattle estancias in the district of the old city of Vera Cruz near the river called Jamapa along the royal highway that goes from the said new city to Mexico and many persons of those who cart goods and travel on the said highway during the rainy season in respect of the river rising are not able to cross and continue there and in order to prevent that damage ... he endeavored to build and found an inn and a boat or canoes for people to cross and proceed ... that well within the 


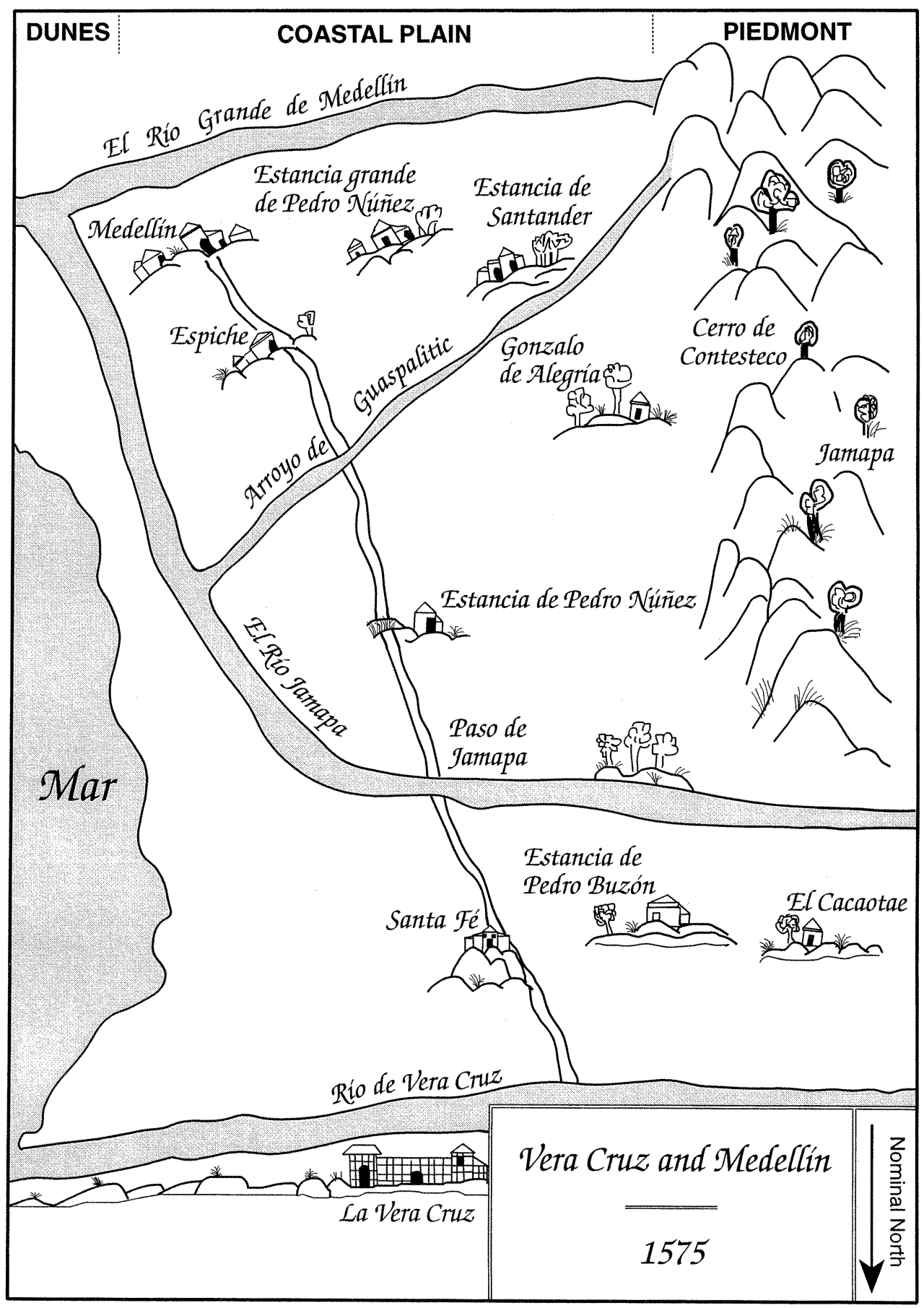

Fig. 2-Transcription of the map related to Juan Rodríguez de Villegas's 1575 request for an estancia along the lower Río Jamapa. Source: AGN, Tierras, vol. 2764, exp. 18, f. 260. 
limits and bounds of the said estancias, next to the river that they call Jamapa, he can establish, build, and found an inn. (AGN, Mercedes, vol. 25, f. 143)

In the toponymic confusion that characterizes these lowlands, the route of the highway changed after Párraga established his venta, or inn, and called it the Venta de Jamapa. The establishment of a second Venta de Jamapa, at the river ford on the new highway, muddied the location of Párraga's original inn. Several eighteenth-century maps, however, help to unravel the shifting toponyms (AGN, Ríos y Acequias, vol. 2, fc. 286-287; AGN, Fomento Caminos, vol. 1, fc. 91; AGN, Indiferente de Guerra, vol. 452A, f. last). The second Venta de Jamapa was at the present-day town of Jamapa. Párraga's Venta de Jamapa was 8 kilometers upstream. That location, now a small village, still retains the toponym if not the inn: La Venta. The Jamapa marked on the 1575 map refers to the native settlement of that name; it lies farther upstream than either of the ventas, among the hills fringing the piedmont, and lay abandoned by 1584 (AGN, Mercedes, vol. 13, ff. 81v-82).

During the first decade or two of the colonial period, then, Gregorio de Villalobos grazed cattle along the banks of the Río Jamapa near the place that was to become the present-day village of La Venta. Even without formal title, a son took over operation of the estancia upon Gregorio's death, sometime before 1547. By 1565, just as Viceroy Luis de Velasco was beginning to formally grant estancias along the Río Jamapa, the son, perhaps having died, had abandoned the estancia.

\section{Transhumant Ecology}

To Gregorio de Villalobos, majordomo to Cortés at Medellín during the 1520s, the country along the lower reaches of the Río Jamapa must have seemed strangely reminiscent of Las Marismas. Like the Arenas Gordas of Andalusia, dunes cut the coastal plain off from the sea. Like the Sierra Morena north of Almonte, mountains rose inland. And, like Las Marismas, the wetlands of Veracruz flooded every year. The seasons were reversed, with the rains coming in spring rather than fall, but the terrain and the rhythm of the floods would have inspired a paisano of Almonte. In scale, Las Marismas dwarfs the Veracruzan wetlands; in 1521, though, the lower Guadalquivir swarmed with cattle, whereas Veracruz had never been grazed. Villalobos wasted no time importing calves, beating the Antillean livestock embargo and founding the cattle-herding ecology of New Spain.

Villalobos chose an estancia that straddled the wet and the dry, just where the Río Jamapa emerged from the hilly fringe of the piedmont and broke onto the coastal plain. From La Venta, the piedmont slopes upward toward the Sierra Madre (Figure 3). The only respite from its dry savanna and patches of deciduous woodland and shrubland comes when leaving the plains and plunging into the verdant ravines of the streams that drain the escarpment and have dissected the Tertiary conglomerates into a ragged apron abutting the coastal plain. Those streams, before cutting through the cordon of sand dunes, form a belt of backswamps that harbor wet savanna studded with palm trees and fringed by evergreen woodlands. The coast itself is a jumble of longitudinal dunes, some cresting at more than 100 meters and trend- 
ing north-south for several kilometers, interspersed with the stagnant ponds that during the nineteenth century harbored the mosquito vectors of yellow fever (Arreola 1982; Siemens 1990).

Carl Christian Sartorius, a nineteenth-century German inhabitant of the district, observed the ecological flux between the dry savanna of the piedmont and the wet

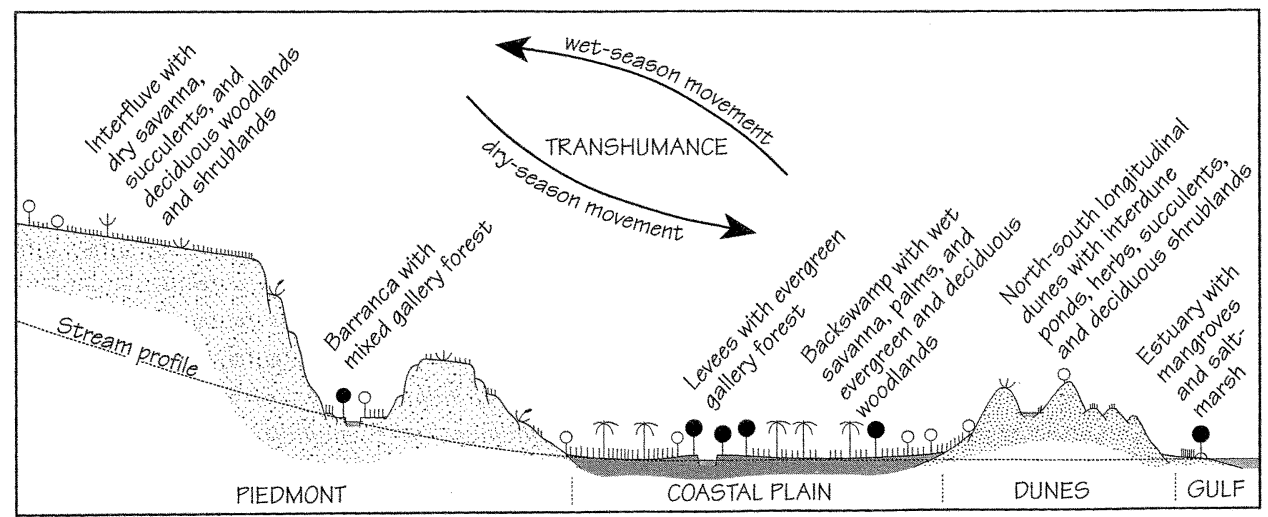

Fig. 3-A generalized transect across the Veracruzan lowland landscape illustrates the regional-scale ecological relationships of transhumance. Compare Figures 1 and 2.

savanna of the coastal plain. His provocative description of local transhumance evokes a sense of how Villalobos, three hundred years earlier, had adapted Andalusian herding practices to the ecology of coastal Veracruz (Sartorius 1961, 4-10). During the summer wet season, Sartorius describes the cattle grazing up on the piedmont. But with "the cessation of the rains, the prairies fade, the soil dries up, the trees lose their foliage, the herds seek the forests and chasms, and in the cloudless skies, the sun scorches up the unsheltered plains" (Sartorius 1961, 9). As the winter dry season progressed and the floodwaters receded from the backswamps, ranchers would drive their cattle downslope to graze the wet savanna (Figure 4). The vaqueros would wait until the piedmont pastures had become tinder dry and set them alight, "partly to destroy the clouds of tormenting ticks and tarantulas, partly to call forth a new crop from beneath the ashes" (Sartorius 1961, 9). In spring, as the floods once again inundated the backswamps, mounted vaqueros rounded up the semiferal cattle and drove them upslope (Figure 5). As the priest of Veracruz hinted in 1571, fires blazed also across the colonial landscape, opening and maintaining pastures: "plains, all made into meadows, ... [are] wont to be burned around Christmas time" (Paso y Troncoso 1905, 5: 194-195). Radiocarbon-dated remains of charred vegetation exhumed from the sediments of the wetlands confirm extensive and persistent burning during the colonial period (Sluyter 1997). The priest also portrays the majority of the cattle as semiferal: "many cows and many wild ones, and many bulls and very fierce" (Paso y Troncoso 1905, 5: 199). 


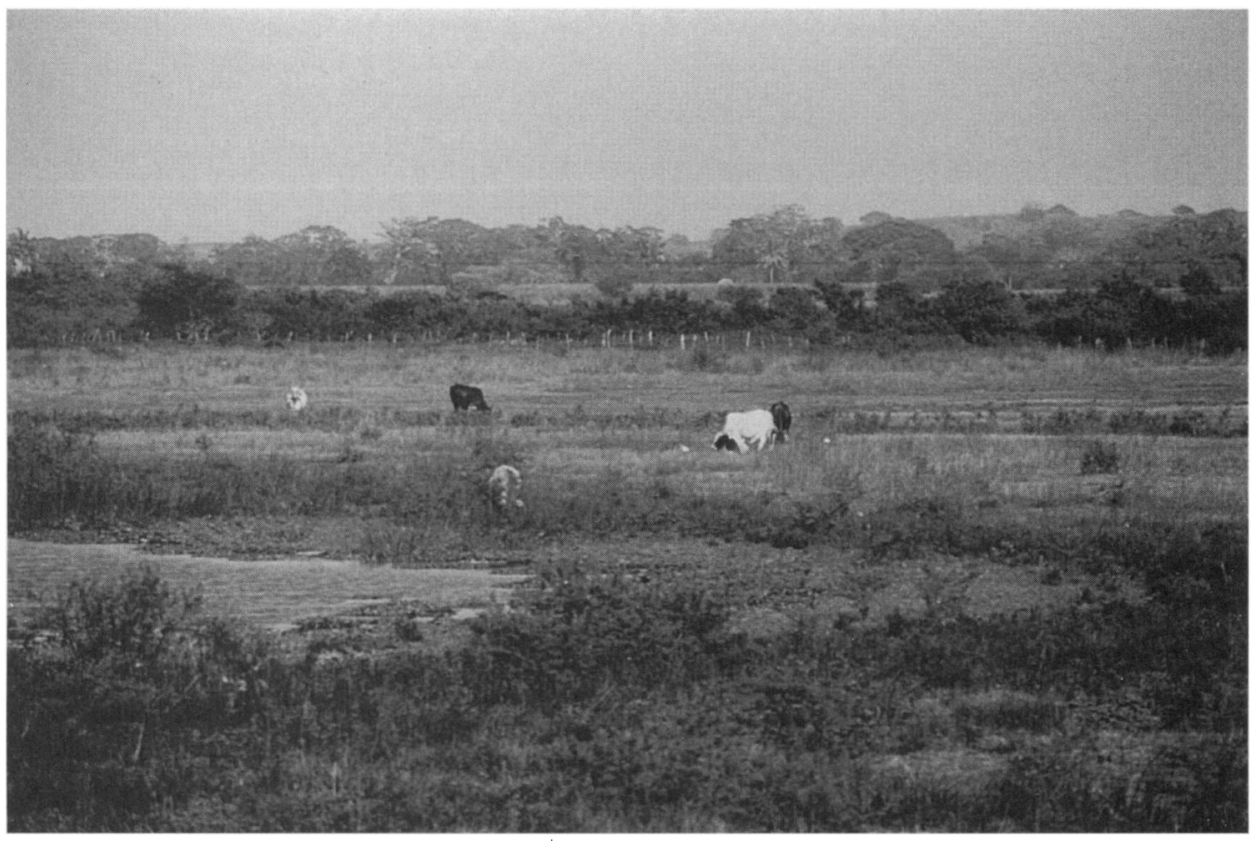

Fig. 4-Cows graze the wet savanna of the coastal plain during the dry season, January 1992. Standing water is in the foreground; higher and drier terrain is in the background. (Photograph by the author)

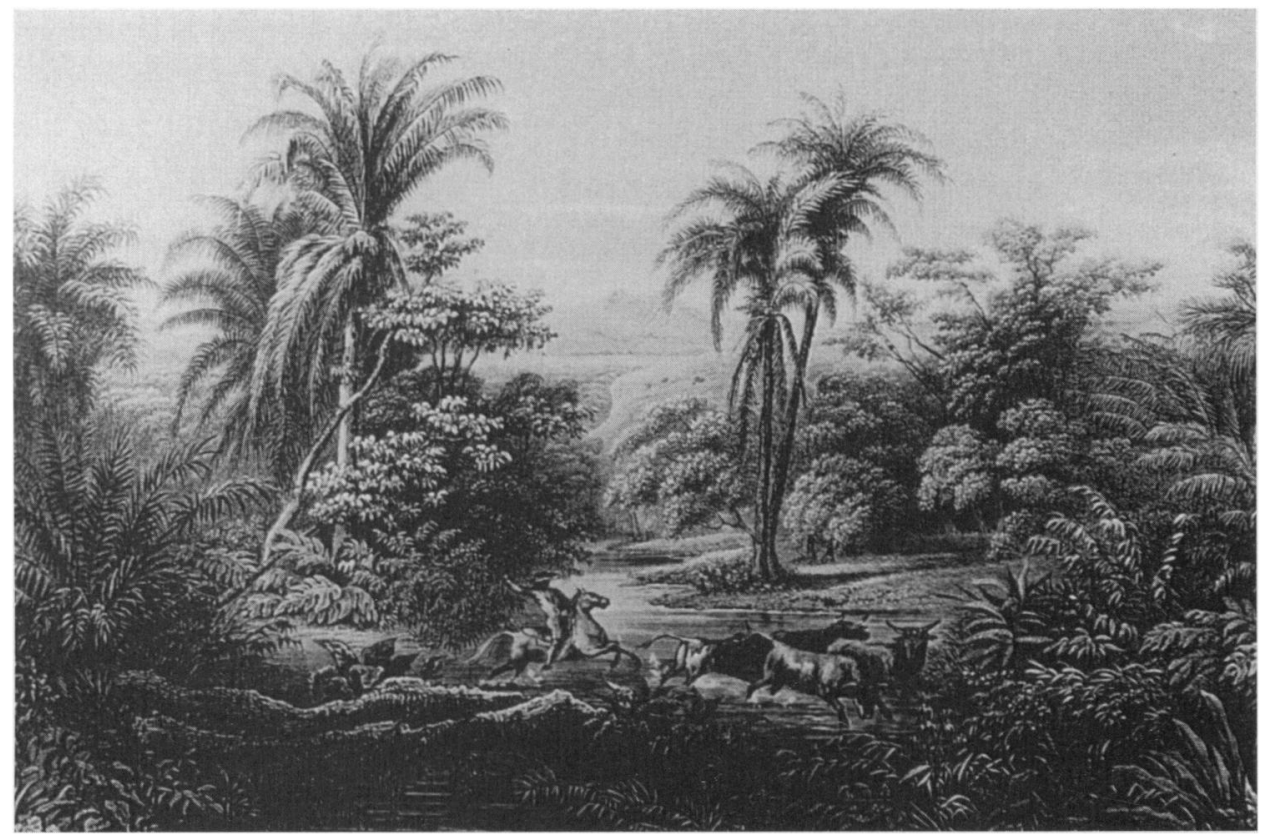

Fig. 5-An engraving of a sketch by Johann Moritz Rugendas illustrates an eighteenth-century roundup in a wetland near the port of Veracruz. Source: Sartorius 1961. 


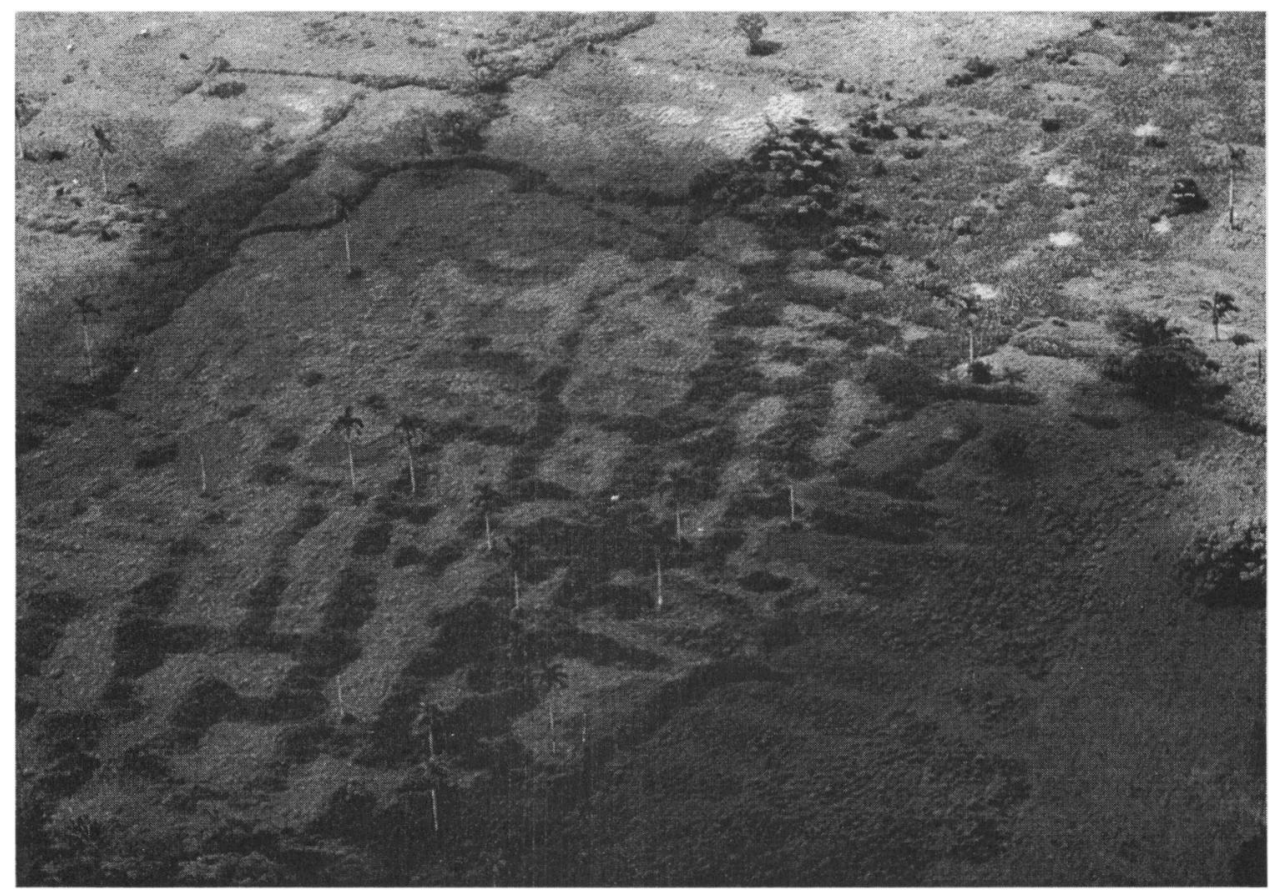

Fig. 6-Cows graze on the coastal plain amid palms and vestiges of pre-Hispanic wetland fields, May 1989. Near the end of the dry season, the darker vegetation accentuates former canals. (Photograph by the author)

\section{Native Ecology and Settrement}

As Villalobos drove his stock down into the wetlands, he probably did not recognize the vestiges of an earlier native ecology. The Spaniards generally seemed unaware that natives had once reconfigured the wetland hydrology by excavating a labyrinth of ditches, now filled with sediment and visible only as vegetational patterning (Figure 6). At the beginning of the rainy season of 1590 , with the fortress of San Juan de Ulúa in sight to the northeast, Hernando de Sarría sat astride his horse atop a dune and surveyed a request for an estancia on the coastal plain below. He noted but did not recognize the significance of relict field patterns: "a small lake which appears in the rainy season ... and marshes ditched straight southward" (AGN, Mercedes, vol. 15, ff. 191-192).

More than 2,000 hectares of such vestiges pattern the belt of wetlands (Siemens 1983a, 1983b). Natives dug ditches and heaped the spoil onto the planting platforms between them. That agroecosystem regulated soil moisture in the root zone of the platforms and maintained a nutrient sump in the ditches, a source of fertilizing muck (Sluyter 1994). The ditches accelerated drainage as the water table fell with the onset of the dry season but retained water for splash and subirrigation as the dry season progressed. While the rain-fed fields of the piedmont lay idle during the dry season, the wetland fields produced a second crop (Sluyter and Siemens 1992). 
Hernando de Sarría's brief description does not clarify the condition of those wetland fields in 1590 , but that they were by then largely derelict seems probable. The north-south ditches that he observed reflect the predominant orientation of such vestiges in the Veracruz lowlands: $15^{\circ}$ east of north (Siemens 1983a). The main avenue at Teotihuacán, the highland city that dominated much of Mesoamerica during the first nine centuries A.D., shares that orientation, suggesting that the wetland fields likely date to considerably before the Spaniards arrived. Excavations of planting platforms and coring of wetlands confirms the chronology: The major period of wetland maize cultivation began during the last several centuries B.C. and ended circa A.D. 500, well before Villalobos grazed his cattle among the vestiges (Siemens and others 1988; Sluyter 1997). Although of more recent vintage, the agricultural systems of the Nahuatl speakers who inhabited the lower Río Jamapa during the Spanish invasion remain less studied regarding form and function. They might well have cultivated wetland fields during the winter and piedmont terraces during the summer, but to what degree and in what manner form the topic of ongoing investigation (Siemens 1983a; Sluyter and Siemens 1992; Siemens 1995; Sluyter 1995).

Regardless, Nahua settlements sprawled across the coastal plain south of San Juan de Ulúa. Depopulation and time have obscured the precise locations, but the Nahua-derived toponyms persist in the archives: Alcocahua, Espiche, Jamapa, Mictlanquautla (JGI, xxV-8; AGN, Tierras, vol. 32, exp. 4; vol. 2672, exp. 8; vol. 2678, exp. 12; vol. 2782, exp. 16; vol. 2680, exp. 20; vol. 2764, exp. 17; vol. 2764, exp. 18). Cotaxtla, an Aztec garrison and the only toponym that survives in its original location, guarded a major route to the highlands along the Río Atoyac (JGI, xxv-8, f. 6). In 1519, according to conquistador Francisco de Aguilar, the population of the entire province, stretching from the Río de la Antigua in the north to Cotaxtla in the south, comprised 40,000 families, possibly nearly a quarter of a million people (Aguilar 1938, 38; Sluyter 1995). According to Charles V's chronicler, 500 families lived at Cotaxtla alone, some two to three thousand people (Mártir de Anglería 1964, 1: 421-422).

With the coming of the Spaniards, war and disease rapidly depopulated those thriving lowlands. The smallpox epidemic of 1520-1521 precipitated most of that demographic apocalypse, possibly as much as three-quarters (Sluyter 1995, 153-167). By 1570 Cotaxtla, Alcocahua, Espiche, Jamapa, Medellín, and Mictlanquautla shared 160 native tribute payers, typically heads of households, representing only some 500 natives living in the major towns of the former province of Cotaxtla (Paso y Troncoso 1939-1940, 14: 82). The Great Cocolixtle, probably a typhus epidemic, had entirely depopulated Alcocahua and Jamapa within another decade (AGN, Tierras, vol. 2678, exp. 12, ff. 5-7).

\section{Ecological Colonialism}

Thus far, only circumstantial data suggest that the Villalobos estancia might have had a direct impact on native ecology and settlement. Fewer than 70 kilometers separated the Villalobos estancia and encomienda of Ixhuatlán, perched at an elevation of 1,200 meters on the escarpment of the Sierra Madre Oriental. By the 1540s 
the Laws of the Indies prohibited encomenderos from running livestock within their encomiendas; but Villalobos and his ranching initiatives preceded that legislation, and earlier practice might have required the natives of Ixhuatlán to work his herds (Recopilación ... 1987, libro 6, título 9, leyes 10-14, 17-20). Delineating those earliest spatial interactions among Spanish and native land uses, control of territory, settlement patterns, and ecologies remains central to understanding the roots of native depopulation and will require further study.

Regardless of whether archival or field research eventually reveals any direct effects that Villalobos might have had on native settlement and ecology, the ecological model for herding cattle that he diffused and adapted from Andalusia proliferated and profoundly altered the native landscape. With the new silver strikes and refining technologies that arrived after 1560, the colonial economy and demand for cattle boomed. In step with increasing immigration from Spain, the urbanized, flesh-eating populations of Mexico City and Puebla grew exponentially, and the mines and their towns demanded tallow and hides. Viceroy Luis de Velasco began to award land grants in the Jamapa region in April 1563; within two decades, cattle estancias had engulfed most of the coastal plain and lower piedmont (AGN, Mercedes, passim; Sluyter 1995). The locations of multiple grants to single ranchers reveal the success of the Villalobos model. For example, Gonzalo de Alegría operated two estancias: the first (Figure 2), down on the coastal plain; the second, up on the piedmont, nearly 20 kilometers to the northwest and the ecological complement of the first (AGN, Mercedes, vol. 13, ff. 73-74). On a grander scale, the Núñez de Montalván brothers, Juan and Pedro, became the first land barons of the Jamapa region by acquiring a string of six estancias between 1564 and 1567 (AGN, Mercedes, vol. 7, ff. 272-273; vol. 8, f. 189; vol. 9, f. 107; vol. 9, ff. 115-116; AGN, Tierras, vol. 32, exp. 4, f. 102). They stretched from the wetlands up onto the lower fringes of the piedmont, spanning the former Nahua province of Cotaxtla (Sluyter 1995). By the 1560 s Gabriel de Villalobos had himself acquired an estancia on the upper piedmont, around 700 meters elevation and 55 kilometers up the Río Jamapa from La Venta (AGN, Tierras, vol. 2719, exp. 33, ff. 386-392).

Viceregal legislation endeavored to protect native culture and ecology from the implanted and expanding pastroecosystem. An ordinance of 1567 proclaimed that native settlements were to encompass a minimum area of one square league, including the surrounding ejido, or commonage (McBride 1923, 123-124). Subsequent legislation confirmed that no cattle estancia was to locate within one and a half leagues of any native settlement (Recopilación... 1987, libro 6, título 3, ley 20). In an attempt to ensure compliance, the merced was merely the final document in a legal process that first required inspection by a Crown officer (Chevalier 1952). An alcalde was to ensure that the grant under consideration would not prejudice the interests of the Crown, the native communities, or the existing grantees by inspecting the actual location of the requested estancia and interviewing local natives. The ensuing reports-in effect, recommendations to the viceroy for or against the grant, sometimes accompanied by maps-at first glance confirm the successful implementation of the 
protective legislation (AGN, Tierras, passim). More careful scrutiny, however, reveals otherwise.

Despite legislation, the native settlements that had survived the smallpox epidemic of 1520-1521 came into conflict with the expanding estancia frontier of the Jamapa region during the 1560 s and early 1570 s. In 1574 Juan de Ocón and Isabel de Vergara received two sheep estancias along the Río Atoyac, harbingers of the imminent land rush for lowland agostadero, or winter pasture, as the flocks of the Mexican plateau began to press the limits of the highland carrying capacity (Melville 1990). In a classic dispute between cattle and sheep herders, the Núñez de Montalván brothers claimed that the Ocon and Vergara grants conflicted with their own, preexisting estancias (AGN, Tierras, vol. 32, exp.4). For good measure, Pedro Núnez revealed that Ocon and the Crown officer recommending the grant had conspired to coerce native acquiescence: "Juan de Ocón bribed the natives and made them drunk so that ... they would not protest" (AGN, Tierras, vol. 32, exp. 4). Equally pithy, the natives of Espiche claimed that cattle had long posed a threat to their crops and livelihood: "[T] here are some cattle estancias three or four leagues from this town which do great damage eating the crops and destroying the fruit trees" (AGN, Tierras, vol. 32, exp. 4).

At the scale of New Spain in its entirety, viceregal protection of natives might be assessed as having been in some measure successful (Butzer and Butzer 1995). Legislation promulgated during the Iberian Reconquista and meant to protect agriculturists from livestock herders and their animals diffused to New Spain along with the cattle. Yet in the environs of the port of Veracruz, and likely elsewhere along the Gulf Coast, the ecology of cattle ranching that Villalobos implanted in the $1520 \mathrm{~s}$ prevented the recovery of native communities already devastated by diseases introduced in the early sixteenth century. Individual Spaniards efficiently circumvented viceregal efforts to protect surviving native culture and ecology with bribery and alcohol. Semiferal cattle moving between coastal plain and piedmont estancias destroyed the surviving native agroecosystems. Weakened by the depredations of the cattle herders, most native communities of the lower Río Jamapa did not withstand the Great Cocolixtle of 1576-1582 and disappeared entirely. By the late sixteenth century, all protective legislation was redundant; laws were "on the books," but there were few natives left to protect.

\section{Persistent Consequences}

Drive inland from the old fortress at San Juan de Ulúa, crest the dune field, look westward, and a sixteenth-century landscape seems to have persisted. The piedmont stretches up toward the glacial cap of Citlaltepetl, and the grass and low thickets sprawl parched and leafless and brown under the cloudless sky of the dry season. The verdant belt of wetlands divides the piedmont and the dunes, its uniqueness and ecological significance still as clear today as it would have been to generations of native peoples and to Gregorio de Villalobos. 
Yet nearly five centuries and many changes do intervene (Saucedo Montemayor 1984; Bermúdez Gorrochotegui 1987; Skerritt Gardner 1989; Siemens 1992, 1995; Sluyter 1995, 1996). By the seventeenth century, capitalizing on Villalobos's initiative, a few families had come to control the vast cattle herds that ranged between coastal plain and piedmont. Emerging out of the ferment of the war for independence two centuries later, General Antonio López de Santa Anna came to dominate these lowlands as thoroughly as he did Mexican politics. Santa Anna's cattle moved between the poles of his hacienda: Manga de Clavo, on the coastal plain, and El Lencero, 1,000 meters upslope. On the eve of Mexico's agrarian revolution, twentieth-century cattle barons still prospered and shipped beef to foreign and domestic urban markets. The major adjustment since the colonial period had been the introduction of more nutritive African grasses and specialized breeds of cattle (La ganadería . . 1965, 13; Parsons 1972; Rouse 1977). After the fall of Porfirio Díaz and the ensuing land reform, rural population density began to rise appreciably from its colonial nadir (INEGI 1990). Mestizo immigrants from the highlands took up ejido lands-expropriated from the haciendas, held in usufruct as communal property, and inalienable. Public funds built the networks of irrigation canals that allowed ejido sugarcane to compete with hacienda cattle, elaborating the connections into the circuits of the global economy. By the passage of the North American Free Trade Agreement and the constitutional amendment that would permit alienation of ejido lands, the ranchers and those ejidal communities tied to the sugar mills had divided the landscape in roughly equal portions (INEGI 1984, 1991). Maize, the dominant crop of a densely populated landscape before the Spanish colonization, now occupies mere interstices-the margins of cane fields and those earthen mounds of pre-Hispanic settlements that have as yet escaped leveling.

The seasonal rhythm of the floods that has been such a vital theme in the lives of the inhabitants of the region persists in some degree, at least for now (Siemens 1995). That seasonal rhythm's spatial corollary-a complementary relationship between piedmont and coastal plain-facilitated the diffusion from Old World to New of the Andalusian ranching ecology and consequently prevented the demographic recovery of the native population. Ranching effectively supplanted native agriculture in the sixteenth century and erased a wealth of agroecological knowledge. By the time farmers began to repossess some of the pastures in the twentieth century, drainage of wetlands, irrigation of drylands, and market integration had become the hopeful watchwords of the prevailing development discourse. Subsistence agriculture was passé. As evidenced in archive and landscape, that outcome involved processes that cut across scales, from global to local and from institutional to individual. So will the possibilities for the future.

\section{Notes}

1. The location of Veracruz shifted four times during the sixteenth century (Sluyter 1995, 412). In 1519, the Spaniards first founded La Villa Rica de la Vera Cruz, albeit in name alone, on the mainland opposite San Juan de Ulúa. Soon thereafter, they refounded and built the town 58 kilometers to the north, at present-day Villa Rica. Circa 1525, the Spaniards dropped "La Villa Rica" from the toponym 
and moved the port to the left bank of the Río de la Antigua, where the present-day town of La Antigua survives. San Juan de Ulúa served as the deepwater port and launches ferried goods from its anchorage along the coast and across the bar of the Río de la Antigua to Vera Cruz. Beginning with a viceregal order of 1597 and progressing over a transitional period of several years, Vera Cruz began the move back to its first location, the mainland opposite the fortress of San Juan de Ulúa and the present-day city of Veracruz.

2. The sources remain equivocal as to the names of the children of Gregorio de Villalobos and García de la Fuente. A document of 1591 names the daughter as Luisa de Villalobos and the son who inherited the encomienda of Ixhuatlán as Baltasar de Padilla (O'Gorman 1941, 214). That son, then, apparently took his paternal grandfather's name, Gregorio de Villalobos having been the son of Diego de Padilla and Teresa de Villalobos of Jerez de la Frontera (Icaza 1923, 1: 223). No document clearly refers to Gabriel de Villalobos as the other son, the one who took over the family estancia. The connection, therefore, remains somewhat conjectural, but it seems sound given the rarity of families named Villalobos in New Spain during the early sixteenth century, although not in the New World (Icaza 1923; O'Gorman 1941; Boyd-Bowman 1964, 1968; Himmerich y Valencia 1991). In fact, only one other Villalobos is associated with the Veracruz lowlands-namely, Pedro de Villalobos-but he was involved in gold mining and returned to Spain a rich man without having married (Millares and Mantecón 1945, 1: 28-29, 333; Boyd-Bowman 1964, 162). Unlike Luisa, both Baltasar and Gabriel seem to have died without heirs (O'Gorman 1941, 214).

3. This and all subsequent translations of quotations from works in languages other than English are by the author.

\section{REFERENCES}

AGN [Archivo General de la Nación, Mexico City]. Various materials.

Aguilar, F. de. 1938 [circa 1560]. Historia de la Nueva España. Mexico City: Ediciones Botas.

Arreola, D. D. 1982. Nineteenth-Century Townscapes of Eastern Mexico. Geographical Review 72 (1): 1-19.

Bermúdez Gorrochotegui, G. 1987. El mayorazgo de la Higuera. Jalapa, Mexico: Universidad Veracruzana.

Bishko, C. J. 1952. The Peninsular Background of Latin American Cattle Ranching. Hispanic American Historical Review 32: 491-515.

Boyd-Bowman, P. 1964. Indice geobiográfico de cuarenta mil pobladores españoles de América en el siglo XVI, tomo I, 1493-1519. Bogotá: Instituto Caro y Cuervo.

-1968. Indice geobiográfico de cuarenta mil pobladores españoles de América en el siglo XVI, tomo II, 1520-1539. Mexico City: Editorial Jus.

Brand, D. D. 1961. The Early History of the Range Cattle Industry in Northern Mexico. Agricultural History 35 (3): 132-139.

Butzer, K. W. 1988. Cattle and Sheep from Old to New Spain: Historical Antecedents. Annals of the Association of American Geographers 78 (1): 29-56.

- 1992. The Americas before and after 1492: An Introduction to Current Geographical Research. Annals of the Association of American Geographers 82 (3): 345-368.

Butzer, K. W., and E. K. Butzer. 1995. Transfer of the Mediterranean Livestock Economy to New Spain: Adaptation and Ecological Consequences. In Global Land Use Change: A Perspective from the Columbian Encounter, edited by B. L. Turner II, A. Gómez Sal, F. González Bernáldez, and F. de Castri, 151-193. Madrid: Consejo Superior de Investigaciones Cientificas.

Chevalier, F. 1952. La formation des grands domaines au Mexique: Terre et societé aux XVI-XVII siècles. Paris: Institut d'Ethnologie.

Cortés, H. 1988 [1519-1526]. Cartas de relacion. Mexico City: Editorial Porrúa.

Crosby, A. W. 1972. The Columbian Exchange: Biological and Cultural Consequences of 1492. Contributions in American Studies, 2. Westport, Conn.: Greenwood Press.

Díaz del Castillo, B. 1986 [1632]. Historia verdadera de la conquista de la Nueva España. Mexico City: Editorial Porrúa.

Doolittle, W.E. 1987. La Marismas to Pánuco to Texas: The Transfer of Open Range Cattle Ranching from Iberia through Northeastern Mexico. Conference of Latin Americanist Geographers Yearbook 13: 3-11. 
Dorantes de Carranza, B. 1987. Sumaria relación de las cosas de la Nueva España, con noticia individual de los conquistadores y primeros pobladores españoles. Mexico City: Editorial Porrúa.

Fernández Alés, R., A. Martín, and J. Merino. 1995. Landscape Change in the Last 500 Years in the Guadalquivir River Valley, Spain, with Special Reference to Donana National Park. In Global Land Use Change: A Perspective from the Columbian Encounter, edited by B. L. Turner II, A. Gomez Sal, F. González Bernáldez, and F. de Castri, 361-376. Madrid: Consejo Superior de Investigaciones Científicas.

La ganaderia en el Estado de Veracruz. 1965. Cuaderno del Instituto de Ciencias, Universidad Veracruzana, 4. Jalapa, Mexico: Universidad Veracruzana.

González Jácome, A. 1988. Población, ambiente y economía en Veracruz central durante la colonia. Mexico City: Universidad lberoamericana.

Gran atlas de España. 1989. Vol. 6, Murcia / Andalucía. Barcelona: Editorial Planeta.

Hackett, C.W., ed. 1923. Historical Documents Relating to New Mexico, Nueva Viscaya, and Approaches Thereto, to 1773. 3 vols. Washington, D.C.: Carnegie Institution of Washington.

Himmerich y Valencia, R. 1991. The Encomenderos of New Spain, 1521-1555. Austin: University of Texas Press.

Icaza, F. A. de, ed. 1923. Diccionario autobiográfico de conquistadores y pobladores de Nueva España. 2 vols. Madrid: Adelantado de Segovia.

INEGI [Instituto Nacional de Estadística, Geografía e Informática]. 1984. Carta uso del suelo y vegetación, Veracruz E14-3. Thematic map, 1:250,000. Mexico City: Instituto Nacional de Estadística, Geografía e Informática.

. 1990. Estadísticas históricas de México. 2 vols. Mexico City: Instituto Nacional de Estadística, Geografía e Informática.

-1991. Atlas ejidal del Estado de Veracruz: Encuesta nacional agropecuaria ejidal, 1988. Mexico City: Instituto Nacional de Estadística, Geografia e Informática.

JGI [Joaquín García Icazbalceta Collection, University of Texas at Austin]. Various materials.

Jordan, T. G. 1993. North American Cattle-Ranching Frontiers: Origins, Diffusion, and Differentiation. Albuquerque: University of New Mexico Press.

Kelly, I., and A. Palerm. 1952. The Tajin Totonac. Part 1, History, Subsistence, Shelter and Technology. Washington, D.C.: Smithsonian Institution.

Mártir de Anglería, P. 1964 [1530]. Decadas del nuevo mundo. 2 vols. Mexico City: Editorial Porrúa.

Matesanz, J. 1965. Introducción de la ganadería en Nueva España, 1521-1525. Historia Mexicana 14 (4): 533-566.

McBride, G. M. 1923. The Land Systems of Mexico. New York: American Geographical Society.

Melgarejo Vivanco, J. L. 1943. Totonacapan. Jalapa, Mexico: Gobierno del Estado de Veracruz.

1975. Breve historia de Veracruz. Jalapa, Mexico: Gobierno del Estado de Veracruz.

Melville, E. G. K. 1990. Environmental and Social Change in the Valle de Mezquital, Mexico, 15211600. Comparative Studies in Society and History 32 (1): 24-53.

Millares Carlo, A., and J. I. Mantecón, eds. 1945. Indice y extractos de los protocolos del Archivo de Notarias de México, D.F. (siglo XVI). 2 vols. Mexico City: El Colegio de México.

O'Gorman, E., ed. 1941. Catálogo de pobladores de Nueva España: Registro de informes de la Real Audiencia, último tercio del siglo XVI-principios del siglo XVII. Mexico City: Archivo General de la Nación.

Parsons, J. J. 1972. Spread of African Pasture Grasses to the American Tropics. Journal of Range Management 25 (1): 12-17.

Paso y Troncoso, F. del, ed. 1905. Papeles de Nueva España. 9 vols. Madrid: Sucesores de Rivadeneyra.

. 1939-1940. Epistolario de Nueva España. 16 vols. Mexico City: Editorial Porrúa.

Recopilación de leyes de los reynos de las Indias. 1987. 5 vols. Mexico City: Editorial Porrúa.

Rouse, J. E. 1977. The Criollo: Spanish Cattle in the Americas. Norman: University of Oklahoma Press.

Sartorius, C. C. 1961. Mexico about 1850. Stuttgart: F. A. Brockhaus. Reprint of Mexico: Landscapes and Popular Sketches. Darmstadt, London, and New York, 1858.

Saucedo Montemayor, P. 1984. Historia de la ganadería en México. Mexico City: Universidad Autónoma de México.

Sauer, C. O. 1941. The Personality of Mexico. Geographical Review 31 (3): 353-364.

1966. The Early Spanish Main. Berkeley: University of California Press. 
Scholes, F. V., and E. B. Adams, eds. 1955. Relación de las encomiendas de indios hechas en Nueva España a los conquistadores y pobladores de ella, año de 1564. Documentos para la Historia del México Colonial, 1. Mexico City: Editorial Porrúa.

Siemens, A. H. 1983a. Oriented Raised Fields in Central Veracruz. American Antiquity 48 (1): 85-102. . 1983b. Wetland Agriculture in Pre-Hispanic Mesoamerica. Geographical Review 73 (2): 166-181.

-1990. Between the Summit and the Sea: Central Veracruz in the Nineteenth Century. Vancouver: University of British Columbia Press.

- 1992. A Favored Place: An Interpretation of the Development of a Wetland Landscape in Central Veracruz, Mexico. In Person, Place, Thing: Interpretive and Empirical Essays in Cultural Geography, edited by Shue Tuck Wong, 195-210. Geoscience and Man, 31. Baton Rouge: Geoscience Publications, Department of Geography and Anthropology, Louisiana State University.

- 1995. Land-Use Succession in the Gulf Lowlands of Mexico. In Global Land Use Change: A Perspective from the Columbian Encounter, edited by B. L. Turner II, A. Gómez Sal, F. González Bernáldez, and F. de Castri, 195-220. Madrid: Consejo Superior de Investigaciones Científicas.

Siemens, A. H., R. J. Hebda, M. Navarrete Hernández, D. R. Piperno, J. K. Stein, and M. G. Zolá Báez. 1988. Evidence for a Cultivar and a Chronology from Patterned Wetlands in Central Veracruz, Mexico. Science 242 (7 October): 105-107.

Simpson, L. B. 1952. Exploitation of Land in Central Mexico in the Sixteenth Century. Ibero-Americana, 36. Berkeley: University of California Press.

Skerritt Gardner, D. 1989. Una historia agraria en el centro de Veracruz, 1850-1940. Jalapa, Mexico: Centro de Investigaciones Históricas, Universidad Veracruzana.

Sluyter, A. 1994. Intensive Wetland Agriculture in Mesoamerica: Space, Time, and Form. Annals of the Association of American Geographers 84 (4): 557-584.

- 1995. Changes in the Landscape: Natives, Spaniards, and the Ecological Restructuration of Central Veracruz, Mexico during the Sixteenth Century. Ph.D. diss., University of Texas at Austin. . 1996. Veracruz (State). In Encyclopedia of Latin American History and Culture, edited by Barbara A. Tenenbaum, 5: 402. New York: Charles Scribner's Sons.

- 1997. Regional, Holocene Records of the Human Dimension of Global Change: Sea-Level and Land-Use Change in Prehistoric Mexico. Global and Planetary Change 14: 127-146.

Sluyter, A., and A. H. Siemens. 1992. Vestiges of Prehispanic, Sloping-Field Terraces on the Piedmont of Central Veracruz, Mexico. Latin American Antiquity 3 (2): 148-160.

Turner, B. L., II, A. Gómez Sal, F. González Bernáldez, and F. de Castri, eds. 1995. Global Land Use Change: A Perspective from the Columbian Encounter. Madrid: Consejo Superior de Investigaciones Científicas.

Watts, D. 1987. The West Indies: Patterns of Development, Culture, and Environmental Change since 1492. Cambridge, England: Cambridge University Press. 